\title{
Research
}

\section{An Investigation of the Criterion Validity of Anadolu Sak Intelligence Scale (ASIS): The Case of EPTS*}

\section{Anadolu Sak Zekâ Ölçeği'nin (ASİS) Ölçüt Geçerliğinin incelenmesi: ÜYEP Örneği}

\author{
Ferhat Köprü ${ }^{1} \&$ M. Bahadır Ayas ${ }^{2}$
}

\begin{abstract}
In this study, the criterion validity of the Anadolu-Sak Intelligence Scale (ASIS) was examined within the scope of the identification system of Education Programs for Talented Students (EPTS). The research participant consisted of 153 students. 30 of them were mathematically and scientifically gifted and 123 were non-gifted by the EPTS identification system. Intelligence scores were obtained by ASIS and talent and creativity scores were obtained by Math Ability Test (MAT) and Creative Scientific Ability Test (CSAT). Findings of the study showed that gifted group's ASIS scores were significantly higher than the non-gifted group's scores. Participants were divided into three groups (upper $27 \%$ middle $46 \%$ lower $27 \%$ ) according EPTS scores and significant differences were found between the average intelligence scores of these three groups $\left[\left(\mathrm{F}_{(2.128)}=49.361, \mathrm{p}<.001 ; \eta^{2}=0.435\right]\right.$. To examine the predictive validity of the ASIS, binary logistic regression analysis was conducted and the model correctly classified $84.3 \%$ of the participants as gifted and non-gifted. For the ASIS's concurrent validity significant correlation coefficients were found between the ASIS scores and EPTS, MAT and CSAT scores (rEPTS = .77; $\mathrm{rMAT}=72 ;$ rCSAT $=.55 ; \mathrm{p}<.001)$. As a result of research findings it can be concluded that ASIS has satisfying criterion validity.
\end{abstract}

Key Words: Anadolu Sak Intelligence Scale, ASIS, criterion validity, mathematical ability, scientific creativity

\section{Öz}

Bu araştırmada Anadolu-Sak Zekâ Ölçeği'nin (ASİS) Üstün Yetenekliler Eğitim Programları (ÜYEP) tanılaması kapsamındaki ölçüt geçerliği incelenmiştir. Araştırmanın katılımcılarını ÜYEP tanılama sınavında özel yetenek tanısı almış 30 öğrenci ve özel yetenek tanısı almayan 123 öğrenci (toplam 153) oluşturmaktadır. Öğrencilerin zekâ düzeyleri ASİS kullanılarak, yetenek ve yaratıcılık puanları ise Matematiksel Yetenek Testi (MYT) ve Bilimsel Üretkenlik Testinden (BÜT) elde edilmiştir. Araştırmadan elde edilen bulgulara göre özel yetenek tanısı alan grubun ASİS puanlarının, özel yetenek tanısı almayan gruba göre anlamlı şekilde daha yüksek olduğu görülmüştür. ÜYEP tanılama puanına göre üst \%27 orta \%46 ve alt \%27'lik dilimlerde yer alan grupların zekâ puanı ortalamaları arasında anlamlı farklar bulunmuştur $\left[\left(\mathrm{F}_{(2.128)}=49.361, \mathrm{p}<.001 ; \eta^{2}=0.435\right]\right.$. ASİS'in tahmin geçerliğini incelemek amacıyla yapılan ikili lojistik regresyon analizi sonucunda, ASİS ÜYEP tanılamasinda özel yetenek tanısı alan ve almayan katılımcıların \%84,3'ünü doğru bir şekilde sınıflamıştır. ASİS'in zamandaş geçerliği analizlerinde ise ÜYEP tanılama puanı, MYT ve BÜT puanları ile genel zekâ arasında anlamlı ilişkiler bulunmuştur (rüYEP= .77; rMYT= .72; гвӥт $=.55 ; \mathrm{p}<.001$ ). Elde edilen bulgulara göre ASİ'in ölçüt geçerliğinin özel yetenek tanılaması bağlamında tatmin edici düzeyde olduğu söylenebilir.

Anahtar Sözcükler: Anadolu Sak Zekâ Ölçeği, ASIS bilimsel yaratıcılık, matematiksel yetenek, ölçüt geçerliği

\section{Summary}

Purpose and Significance: ASIS is the first and new intelligence scale developed in Turkish culture (Sak et al., 2016). It is also used by the Ministry of National Education as a basic identification tool

\footnotetext{
* The paper is based on the first author's master thesis

${ }^{1}$ Corresponding Author, MS, Research Assistant, Anadolu University, Faculty of Education, Eskisehir, Turkey, ferhatkopru@anadolu.edu.tr, ORCID: 0000-0002-5297-948X

${ }^{2}$ Assist. Prof. Center for Research and Practice for High Ability Education (EPTS), Anadolu University, Faculty of Education, Eskisehir, Turkey, ORCID:0000-0002-7560-9465

(C) Talent; ISSN 2717-7122 http://talentjournal.net
} 
for the identification of giftedness. Therefore, it becomes more important to conduct additional research on criterion validity of ASIS. In this context, it is aimed to examine the criterion validity of ASIS in the identification process of giftedness in this study. With this respect discriminant and predictive validity analysis was performed within the scope of giftedness label and concurrent validity analyzes were conducted within the scope of mathematical ability and scientific creativity measurements.

Method: Research participants included 153 fifth grade students. 30 of them were identified as gifted by the EPTS identification process. 123 of them were selected by systemic sampling among those who were not identified as gifted. ASIS, Mathematical Ability Test (MAT) and Creative Scientific Ability Test (CSAT) were used as data collection tools.

Discriminant validity, predictive validity and concurrent validity were examined within the scope of criterion validity. Independent sample $t$ test and one way ANOVA analysis were performed to investigate the discriminant validity of ASIS. In order to examine the predictive validity of ASIS, a binary logistic regression analysis was performed. In the context of the concurrent validity of ASIS, Pearson Moments Multiplication Correlation Analysis was conducted to examine the relationship between intelligence and mathematical ability and scientific creativity.

Results and conclusion: The independent sample t-test was used to examine discriminant validity. The analysis showed that gifted students have significantly higher intelligence scores than their non-gifted peers. In addition to this, participants were divided into three ability groups (high \%27, middle \%46, and low \% 27) according to their EPTS scores and the intelligence scores of the groups were compared by using one way ANOVA. There was a statistically significant difference between the average intelligence scores of the students in different ability groups $\left(\mathrm{F}_{(2.128)}=49.361, \mathrm{p}<.001 ; \mathrm{\eta}^{2}\right.$ $=0.435$ ). To examine the predictive validity of the ASIS, the binary logistic regression analysis was performed. It was found that the model correctly classified $84.3 \%$ of the participants as gifted and non-gifted. The relationship between the general intelligence score of ASIS, EPTS, MAT and CSAT scores was investigated using Pearson Moments Multiplication Correlation Analysis to examine concurrent validity of ASIS. There was a strong and positive correlation between ASIS scores and EPTS, MAT and moderate between CSAT scores ( $\mathrm{rEPTS}=.77$; $\mathrm{rMAT}=72 ; \mathrm{rCSAT}=.55 ; \mathrm{p}<.001$ ). In conclusion the research findings support the criterion validity of ASIS.

\section{Giriş}

Zekâ kuramları tarihsel perspektifte incelendiğinde tek boyutlu genel zekâ tanımlarından çok boyutlu zekâ tanımlarına doğru bir değişim yaşandığı görülmektedir (Sak, 2013). Yeni kuramların ortaya atılması, zekâ ölçümde kullanılan araçların revize edilmesine, bu kuramlarla örtüşen yeni zekâ testlerinin geliştirilmesine ve zekâ testlerinin yaygın şekilde kullanılmasına neden olmuştur. Zekâ testlerinin sınıflama, eğitsel farklılaştırma, eğitimin niteliğinin arttırılması, tıbbi, klinik ve eğitsel tanı gibi işlevlerinden dolayı kullanımı yaygınlaşmış ve zekâ testlerinin temel kalite standartlarını oluşturan geçerlik ve güvenirlik bulguları daha önemli hale gelmiştir (Sak vd., 2016). Bu bakımdan farklı yöntemlerle ve farklı gruplardan elde edilecek veriler üzerinden zekâ testlerinin geçerlik ve güvenirliklerine ilişkin ek kanıtların sunulması, revizyon veya yeni zekâ testi geliştirme 
süreçlerinin önemli bir boyutunu oluşturmaktadır.

Zekâ testlerinin geçerlik ve güvenirlik raporları incelendiğinde yapı geçerliği ve güvenirlik analizlerinde büyük benzerliklere rastlanırken, zamandaş geçerlik ve tahmin geçerliğini kapsayan ölçüt geçerliği çalışmalarında kullanılan analiz yöntemleri ve ölçütlerin çeşitliliği göze çarpmaktadır. Yaygın kullanılan zekâ testlerinin manuelleri incelendiğinde ölçüt geçerliği çalışmalarının testin geliştirilme amaçları ve kültürel değişkenler bağlamında şekillendiği görülmektedir. Dolayısı ile birçok zekâ testinin kılavuzunda ölçüt geçerliliğine ilişkin kanıtların sınırlılığından söz edilebilir. Örneğin yaygın kullanılan Wechsler (WISC) ve Stanford-Binet (SB) zekâ testlerinin farklı sürümleri incelendiğinde ölçüt geçerliği için yaş, akademik başarı, diğer zekâ testleri ve farklı özel gereksinim gruplarının zekâ testi puanlarının kullanıldığı görülmektedir. Her ne kadar manuellerde rapor edilen geçerlik bulguları tatmin edici düzeyde olsa da, bu testlerin zekâ ile ilişkili olduğu bilinen yetenek (Carvajal et al., 1989) yaratıcılık (Sternberg \& O'Hara, 1999) ve özel yeteneklilik tanısı bağlamında ölçüt geçerliği çalışmalarının ek araştırmalarla ortaya koyulduğu görülmektedir.

Türk kültüründe geliştirilen ilk zekâ testi olan Anadolu Sak Zekâ Ölçeği'nin (ASİS) ölçüt geçerliği çalışmaları için yaş, karne notları, diğer zekâ testleri ile ilişkisi ve farklı özel gereksinim gruplarının zekâ testi sonuçlarının kullanıldığı görülmektedir (Sak vd., 2016). ASİS'in yeni ve Türk kültüründe geliştirilen ilk zekâ ölçeği olması, gerekse Milli Eğitim Bakanlığı (MEB) tarafından özel yetenekli öğrencilerin belirlenmesinde temel tanı aracı olarak kullanılması nedeniyle ölçüt geçerliğine ilişkin ek araştırmaların yapılması daha da önemli hale gelmektedir. Bu bağlamda, ASIS'in ölçüt geçerliğinin yeni ölçütler bağlamında incelenmesi amacıyla bu araştırmada ASIS'in matematik yeteneği ve bilimsel yaratıcılık ölçümleri bağlamında zamandaş geçerliği ve özel yetenek tanısı bağlamında ise tahmin ve ayırt edicilik geçerliği analizleri yapılmıştır.

\section{Özel Yeteneğin Tanılanması}

Özel yetenek kavramının tarihsel süreçte tek boyutlu tanımlardan çok boyutlu tanımlara doğru bir değişim içinde olduğu söylenebilir. Geleneksel yaklaşımlarda özel yetenek kavramı sadece zekâ ile ilişkilendirilirken (örneğin Terman, 1926), çağdaş yaklaşımlarda herhangi bir alandaki üst düzey performansla ilişkilendirilmektedir (Gagne, 2004; Monks \& Katzko, 2005; Plucker \& Barab, 2005). Çağdaş özel yetenek kuramlarında üst düzey performansa vurgu yapılsa da birçok kuramda zekâ önemli bir bileşen olarak kuramlara eklenmektedir. Örneğin Üçlü Halka Kuramı'nın ortalama üstü yetenek bileşeninin (Renzulli, 1978), Ayrımsal Üstün Zekâ ve Yetenek Kuramı'nın doğal yetenekler altında verilen zihinsel yetenek bileşeninin (Gagne, 2004) ve Başarılı Zekâ Kuramı'nın analitik beceriler bileşeninin (Sternberg, 1999) genel zekâ ile ilişkili olarak tanımlandığı görülmektedir. Bu bakımdan özel yeteneğin tanılanmasında zekâ ölçümlerinin gerekli fakat tek başına yeterli olmayacağı düşünülebilir. Çünkü tanılama süreçlerinde tek başına zekâ testlerinin kullanılması (DeRidder, 1987) veya tek başına alana özgü becerilerin ölçülmesi (Feldhusen, et al., 1993) tanım, tanılama ve program içeriği arasında uyum problemlerine, farklı bir ifade ile geçerlik sorunlarına neden olabilmektedir. Bu bakımdan özel yeteneklilere yönelik eğitim programlarına öğrenci seçimlerinde zekâ ve alana özgü becerileri kapsayan çoklu ölçümlere yer verilmesi önerilmektedir. 
Tanılama uygulamaları Türkiye özelinde incelendiğinde karşımıza Üstün Yetenekliler Eğitim Programları (ÜYEP) ve Bilim ve Sanat Merkezleri (BİLSEM) program modelleri çıkmaktadır. BİLSEM tanılama sürecinde öğretmen veya aile değerlendirme formu, tarama sınavı ve ASİS verileri kullanılmaktadır. Süreçte ASİS puanı mutlak ölçüt olarak kullanılmakta ve ASİS genel zekâ endeksi (GIQ) 130 IQ ve üzerinde olan öğrenciler programa kabul edilmektedir. ÜYEP tanılama sürecinde ise genel yetenek, matematik yeteneği ve bilimsel yaratıcılığa özgü testler uygulanarak test puanları birleştirilmektedir (Sak, 2011). Bu bakımdan mevcut araştırmanın konusu olan ASİ'in ölçüt geçerliği için özel yetenek tanısının BİLSEM tanılama süreci bağlamında değerlendirilmesi anlamsız olacaktır. Bu bağlamda özel yetenek tanısı verilmesi ve çoklu ölçüme (genel yetenek, matematik yeteneği ve bilimsel yaratıcılık) dayalı bir tanılama süreci olması bakımından, ASIS' in ölçüt geçerliğine ilişkin ek değerlendirmelerin yapılabilmesi için ÜYEP tanılama süreci daha anlamlı olacaktır.

\section{Zekâ ve Matematiksel Yetenek İlişkisi}

Alanyazında matematiksel yetenek ile ilgili birçok tanım vardır. Matematik yeteneği, dünyaya matematikçi gözü ile bakma olarak ifade edilen matematiksel düşünme becerisi (Krutetskii, 1976); belirli bir zamanda matematiğin herhangi bir dalında üretim veya problem çözme becerisi (Sak, 2008) ve matematiksel bilgiyi etkili kullanabilme becerisi (Koshy, et al., 2010) olarak tanımlanmaktadır. Bu tanımlar incelendiğinde ise sıklıkla analitik yetenek (Hadamard, 1945; Guilford, 1967; Wrigley, 1958) ve alan bilgisi (Ericsson, 2003; Gagne, 2004; Renzulli, 1978; Sternberg, 1999,) matematik yeteneğinin bileşenleri arasında yer almaktadır. Matematiksel yeteneğin bileşenlerinden kabul edilen analitik yeteneğe (Gottfredsson, 1997; Sternberg, 1999) ve bilgi/alan bilgisine (Jensen, 1988) zekâ tanımlarında ve zekâ testlerinde sıklıkla yer verildiği görülmektedir. Bu bakımdan zekâ ile matematik yeteneği arasında bir ilişki olduğu ve matematik yetenek testlerinin zekâ testlerinin ölçüt geçerlik çalışmalarında kullanılabileceği düşünülebilir.

Zekâ ile matematik yeteneği arasındaki ilişkiye dair araştırmaların sınırlı olduğu ve sınırlı sayıdaki bu araştırmalarda ise hesaplanan korelasyon katsayılarının orta ve yüksek düzeyde olduğu görülmektedir. Örneğin, Carvajal et al. (1989) zekâ ile matematiksel yetenek arasındaki ilişkiyi incelemek amacıyla 30 kişilik katılımcı grubuna WAİS-R ve ACT (American College Test) uygulamış ve zekâ ile matematiksel yetenek arasında yüksek korelasyon katsayısı rapor etmiştir $(\mathrm{r}=.81 ; \mathrm{p}<.01)$. Benzer şekilde Steinberg et al. (1967) ilişki düzeyini $r=.72$ ( $p<.01)$ olarak raporlamıştır. Yine Koenig et al. (2008) zekâyı ASVAB (Armed Services Vocational Aptitude Battery) ile değerlendirmiş, matematiksel yeteneği ise ACTve Scholastic Aptitude Test (SAT) ile değerlendirmiş, zekâ ve matematik yeteneği arasında $\mathrm{r}=.743$ ile $\mathrm{r}=.782(\mathrm{p}<.01)$ arasında değişen korelasyon katsayıları rapor etmiştir.

Matematik yeteneğinin önemli bir bileşeni olan alan bilgisinin zekâ ile ilişkisi üzerine yapılan araştırmalar incelendiğinde ise genel olarak orta düzeyde ilişki katsayılarının raporlandığı görülmektedir. Örneğin matematik alan bilgisi ile zekâ arasındaki ilişki düzeyini Oakland (1983) r=.66 $(\mathrm{p}<.01)$, Dean $(1979) \mathrm{r}=.55(\mathrm{p}<.01)$ ve Hartlage \& Boone (1977) $\mathrm{r}=.56(\mathrm{p}<.01)$ olarak rapor etmiştir. Karnes et al. (1986) ise $\mathrm{r}=.40$ ( $\mathrm{p}<.01)$ olarak raporlamışlardır. Ayrıca zekâ testlerinin ölçüt çalışma- 
larında da matematik başarının kullanıldığı görülmektedir. Bu bakımdan matematik başarı ve yetenek ölçümlerinin araştırmaya konu olan ASIS' in ölçüt geçerliği çalışmaları kapsamında matematik karne notlarının da kullanıldığı görülmektedir (Sak vd., 2016). Dülger (2018) ASİS genel zekâ endeksi (GIQ) ile matematik karne notu arasında $\mathrm{r}=.82$ ( $\mathrm{p}<.001)$ düzeyinde korelasyon katsayısı rapor etmiştir. Ancak okullarda öğretmenlerin not verme pratikleri ve veri tutarlılığ düşünüldüğünde (Geiser, 2009) zekâ testlerinin ölçüt geçerliği çalışmalarında standart başarı ve yetenek testlerinin kullanılması daha doğru olacaktır. Bu bakımdan ÜYEP tanılamasında kullanılan ve matematik alan bilgisini de kapsayan standart bir test olan Matematiksel Yetenek Testi (MYT) puanları ile ASİS puanları arasındaki ilişkinin ortaya koyulmasının, ASIS'in ölçüt geçerliğine ilişkin daha objektif veriler sunacağı düşünülebilir.

\section{Zekâ ve Bilimsel Yaratıcılık İlişkisi}

Yaratıcılığa, çağdaş özel yetenek tanım ve kuramlarında sıklıkla yer verildiği görülmektedir (Renzulli, 1978; Sternberg, 1999). 19. Yüzyılın ortalarında hız kazanan yaratıcılık çalışmaları incelendiğinde bazı çalışmalarda zekâ yaratıcılığın bir alt bileşeni, bazı çalışmalarda yaratıcılık zekânın alt bileşeni, bazı çalışmalarda yaratıcılık ve zekâ örtüşen kavramlar, bazı çalışmalarda ise zekâ ve yaratıcılık tamamen farklı veya tamamen aynı kavramlar olarak tanımlanmaktadır (Sternberg \& O'Hara, 1999). Farklı yaklaşımlar olmakla birlikte zekâ ve yaratıcılık arasındaki ilişkinin genellikle Eşik Hipotezi (Guilford, 1967) ile açıklanmaya çalışıldığı görülmektedir. Eşik hipotezine göre zekâ ve yaratıcılık arasında belirli bir zekâ düzeyine kadar gözlenen anlamlı ilişkiye (genellikle 120 IQ), bu eşik değerin üzerinde rastlanmamaktadır. Farklı bir ifade ile eşik zekâ değerine kadar zekâ ve yaratıcılık arasında pozitif ve anlamlı korelasyon katsayıları, eşik değerin üzerinde kaybolmaktadir.

Eşik hipotezi çalışmaları incelendiğinde tutarsız araştırma bulgularının olduğu göze çarpmaktadır. Bazı çalışmalarda eşik hipotezi doğrulanırken (Cho, et al., 2010; Getzels \& Jackson, 1962; Shi et al., 2017), bazılarında herhangi bir eşik zekâ değerin bulunamadığı (Preckel et al., 2006), bazılarında ise eşik hipotezi için ters ilişkiler rapor edildiği (Sligh et al., 2005; Bermejo et al.,2016) görülmektedir. Zekâ ve yaratıcılık arasındaki ilişkinin eşik hipotezinden bağımsız bir şekilde incelendiği çalışmalarda ise genellikle zayıf ve orta derecede korelasyon katsayılarının rapor edildiği görülmektedir (Sternberg \& O’Hara, 1999). Örneğin Kim (2008) yaptığı meta-analiz çalışmasında zekâ ile yaratıcılık arasındaki ilişkinin genel olarak r=.20 civarında olduğu rapor edilmiştir. Özel yetenek tanısı bağlamında zekâ ve yaratıcılık ilişkisinin incelendiği araştırmalarda ise nispeten daha yüksek korelasyon katsayılarının rapor edildiği görülmektedir. Örneğin, Runco \& Albert (1986) yaptıkları araştırmada zekâ ile yaratıcılık arasındaki ilişkiyi incelemiş ve normal üstü zekâya sahip grupta zekâ ile akıcılık arasında .58 zekâ ile orijinallik arasında ise .52 düzeyinde ilişki katsayıları rapor etmişlerdir.

Zekâ ve yaratıcılık arasındaki ilişki, ölçülecek yapılar ve ölçüme araçlarına göre farklılaşmaktadır (Preckel et al., 2006). Bu bakımdan kullanılan yaratıcılık testinin genel veya alana özgü olup olmamasının sonuçları etkileyeceği düşünülebilir. Alana özgü yaratıcılık testlerinin alan bilgisi içermesinden dolayı (Ayas \& Sak, 2014; Hu \& Adey, 2002) zekâ ile alana özgü yaratıcılık arasında anlamlı bir ilişki olması beklenebilir. Ancak alana özgü yaratıcılık ve zekâ arasındaki ilişkinin araştırıldığı 
sınırlı sayıdaki araştırmada ise genellikle düşük düzeyde korelasyon katsayılarının rapor edildiği (An et al., 2016; Gough, 1975), orta yaş ve üzerindeki katılımcılarla yürütülen çalışmalarda ise orta düzeyde korelasyon katsayılarının rapor edildiği görülmektedir (Simonton, 1976; Park et al., 2007). Bu durumun nedeni yaş ile birlikte artan tecrübe ve alan bilgisi olabilir. Bu bağlamda ÜYEP tanılamalarında kullanılan Bilimsel Üretkenlik Testi'nin (BÜT) ASİ' in ölçüt geçerliğini incelemek için kullanılabileceği düşünülebilir.

\section{Yöntem}

\section{Çalışma Grubu}

Araştırmanın çalışma grubunu Eskişehir ilinde Milli Eğitim Bakanlığına bağlı okullarda öğrenim görüp, ÜYEP tanılama sınavına giren öğrenciler arasından sistematik ve amaçlı örneklem yolu ile belirlenen 153 beşinci sınıf öğrencisi oluşturmaktadır. Katılımcı grubunda yer alan 30 öğrenci ÜYEP'e kayıt yaptırma hakkı kazanan özel yetenekli öğrencilerdir. 123 öğrenci ise programa kayıt hakkı kazanamayan öğrenciler arasından, popülasyon üzerinde daha eşit dağılan bir örneklem elde etmek amacıyla, sistematik örnekleme yöntemi (4'te 1) kullanılarak seçilmiştir (Şenyay, 2011). ÜYEP'e 2019 yılında 500 aday öğrenci başvurmuş ve adaylar arasında farklı yetenek düzeylerindeki öğrencilere ulaşmak hedeflendiğinden bu örnekleme yöntemi tercih edilmiştir.

Örneklem ve çalışma evrenine (toplam aday) ilişkin katılımcı sayıları ve örneklemin temsil düzeyine ilişkin yorum yapabilmek amacıyla evren ve örnekleme ilişkin bilgiler Tablo.1' de verilmiştir.

Tablo 1. Katılımcı Grubuna İlişkin Betimsel Bulgular

\begin{tabular}{llll}
\hline & Cinsiyet & $\mathbf{n}$ & $\mathbf{\%}$ \\
\hline \multirow{3}{*}{ Örneklem } & Erkek & 84 & 54,9 \\
& Kiz & 69 & 45,1 \\
& Toplam & 153 & 100 \\
\hline \multirow{3}{*}{ Toplam Aday } & Erkek & 276 & 55,2 \\
& Kiz & 224 & 44,8 \\
& Toplam & 500 & 100 \\
\hline
\end{tabular}

Seçilen örneklemin ÜYEP tanılama puanlarının varyansının $\left(S^{2}=265,82\right)$ tüm adayların oluşturduğu grubunun varyansından $\left(\sigma^{2}=174,37\right)$ büyük olduğu bulunmuştur. Örneklemin iç varyansının evrenin varyansından yüksek olması, örneklemin kendi içerisinde heterojen ve güvenilir bir yapı gösterdiği şeklinde yorumlanabilir (Şenyay, 2011). Örneklemin ve toplam aday grubunun ÜYEP tanılama puanlarının standart sapması birbirine yakın değerler aldığı görülmüştür. Örneklem ve toplam adaylarda yer alan erkek ve kız öğrenci oranlarının oldukça yakın olduğu görülmektedir. Bu bakımdan seçilen örneklemin evreni oldukça iyi düzeyde temsil ettiğini söylenebilir.

\section{Veri Toplama Aracı}

Araştırmada veri toplama aracı olarak, ASİS ve ÜYEP tanılamasında kullanılan Matematiksel Yetenek Testi (MYT) ve Bilimsel Üretkenlik Testi (BÜT) kullanılmıştır. Araçlara ilişkin bilgiler aşağıda detaylı şekilde açıklanmıştır. 
Anadolu Sak Zekâ Ölçeği (ASİS). Türkiye'nin ilk yerli zekâ ölçeği olan ASİs, 4-12 yaş grubunda yer alan çocukların zihinsel kapasitelerini ölçmek amaciyla bireysel olarak uygulanan bir zekâ ölçeğidir (Sak vd., 2016). Kullanım alanı oldukça geniş olan ASİS, öncelikli olarak zihinsel kapasiteyi değerlendirmeyi amaçlamaktadır. Ayrıca zihinsel gelişim yetersizliğine sahip, öğrenme bozukluğu yaşayan veya bellek zayıflığı ve dikkat eksikliği olan çocukların tanılanması amacıyla da kullanabilen bir testtir (Sak vd., 2016).

ASIS'in güvenirlik analizlerinde iç tutarlılık, test tekrar test ve puanlayıcılar arası güvenirlik analizleri yapılmıştır. Analiz sonuçlarında alt endekslere göre ASİ'in iç tutarlılık güvenirliğinin .95 ve .99 arasında değiştiği, test tekrar test güvenirliğinin .85 ve .89 arasında değiştiği ve puanlayıcılar arası güvenirlik değerlerinin ise .96 ile 1.00 arasında değiştiği rapor edilmiştir (Sak vd., 2016). ASIS' in geçerlik çalışmalarında yapı geçerliği çalışması için yapılan açımlayıcı faktör analizi (AFA) sonucuna göre yedi alt testin genel zekâ faktörü altında toplandığı görülmüş, Doğrulayıcı Faktör Analizi (DFA) bulgularında ise AFA bulguları doğrulanarak ASİ' in teorik alt yapısının CHC kuramına uygun olarak oluşturulduğu görülmüştür (Sak vd., 2016).

ASIS ölçüt geçerliğini incelemek amacıyla yaş, eğitim düzeyi, akademik başarı ve zekâ testleri gibi dış ölçütler kullanılmıştır. Akademik başarı için kullanılan karne notları ile ASİS genel zekâ endeksi arasında .80 ( $\mathrm{p}<.001)$ düzeyinde; gelişimsel geçerlik için kullanılan yaş ve eğitim düzeyi ile ASIS genel zekâ endeksi arasında sırasıyla .75 ve .74 (p<.001) düzeyinde ilişki katsayıları bulunmuştur. ASİS, uyum geçerliği bağlamında ise Reynold Bilişsel Değerlendirme Sistemi (RIAS) ve Evrensel Sözel Olmayan Zekâ Ölçeği (UNIT) ile karşılaştırılmıştır. ASISS ile RIAS bileşenleri arasındaki korelasyon değerleri .65 ile .82 arasında değer alırken UNIT bileşenleri arasında .57 ile .79 arasında değiştiği görülmüştür (Dülger, 2018). ASIS'in ayırt edicilik geçerliği kapsamında yapılan çalışmalarda ise ASİ'in özel eğitim grupları (zihin yetersizliği, otizm, öğrenme güçlüğü, özel yetenek) arası ayırt edici geçerliğine ilişkin kanıtlar elde etmiştir (Sözel vd., 2018; Cirik vd., 2020).

Araştırmanın konusu olan ASİS ölçüt geçerliği çalışmaları detaylı incelendiğinde, ASİS'in akademik başarı ile zamandaş geçerlik çalışmasının okul notları üzerinden yapıldığı görülmektedir. Karne notlarının sosyo-ekonomik düzey ve öğretmen tutumları ve tecrübe düzeyi gibi değişkenler bağlamında değiştiği bilinmektedir. Bu bakımdan ölçüt geçerliği çalışmalarında standart akademik başarı ölçümleri önerilmektedir. ASİS'in ayırt edicilik geçerliği için yapılan analizlerde, klinik grupların ASISS puanlarının kullanıldığı görülmektedir. Bu analizlerde daha önceden tanı almış bireylerin kullanılması bulguların yorumlanması bakımından sınırlılık yaratabilir. Bu bakımdan ayırt edicilik geçerliğine de ek kanıt sağlamak amacıyla ASİS'in özel yetenek tanılama sürecinde, özel yetenekli öğrencileri tahmin geçerliği çalışmasının yapılması önemlidir. Son olarak zekâ ve yaratıcılık arasındaki ilişkiye dair alanyazında var olan araştırma bulguları düşünüldügünde ASIS'in ölçüt geçerliği için yaratıcılık testlerinin de kullanılabileceği düşünülebilir.

Üstün Yetenekliler Eğitim Programları (ÜYEP). ÜYEP matematik ve fen alanında özel yetenekli ortaokul öğrencilerine eğitim sunmak amacıyla Anadolu Üniversitesinde faaliyet gösteren bir eğitim programıdır. Program, matematik ve fen alanında özel yetenekli öğrencilere zenginleştirilmiş ve hızlandırılmış bir müfredat sunmaktadır (Sak, 2011). ÜYEP tanılama sürecinde örnek- 
leme dayalı tanılama yaklaşımı benimsenmekte ve alana özgü yetenek ve yaratıcılık ölçümleri yapılmaktadır. Tanılama sürecine başvuru için 5. sınıf öğrencisi olmanın dışında herhangi bir şart ise aranmamaktadır (Sak, 2011). ÜYEP tanılamasında kullanılan MYT ve BÜT puanları, standart sapması 15 ortalaması 100 olacak şekilde standart puan dönüşümü yapılarak sırası ile \%70 ve \%30 ağırlıkları alınarak birleştirilmekte ve ÜYEP tanılama puanı elde edilmektedir. Tanılama puanlarına göre başarı sıralaması yapılan öğrencilerden ilk 30 öğrenciye özel yetenek tanısı verilmekte, 28 öğrenciye programa kayıt yaptırma hakkı verilmekte, 2 öğrenci ise yedek öğrenci olarak listelenmektedir.

Matematiksel Yetenek Testi (MYT). Matematiksel Yetenek Testi (MYT), matematik alanında özel yetenekli öğrencileri tanılamak amacıyla Sak ve diğerleri (2008) tarafından geliştirilmiştir. MYT, Üçlü Matematik Yetenek Modeli (Sak, 2008) temel alınarak geliştirilmiştir. Bu model matematiksel yeteneğin analitik yetenek, yaratıcılık ve alan uzmanlığının birleşmesiyle ortaya çıtığını öne sürmektedir. MYT alan bilgisi ve genel yetenek olmak üzere iki kısımdan ve toplamda 42 çoktan seçmeli maddeden oluşmaktadır. MYT'nin güvenirlik ve geçerlik analizleri yapılmış ve elde edilen bulgular, MYT'nin güvenilir ve geçerli bir test olduğunu göstermektedir (Sak vd., 2008,). MYT'nin güvenirliği bağlamında testin iç tutarlılık güvenirliğini belirlemek amacıyla KR-20 testi yapılmış ve güvenirlik katsayısı .80 olarak raporlanmıştır.

Mevcut araştırma kapsamında MYT'nin çoktan seçmeli bir test olması ve maddelerin kolaydan zora doğru sıralanmış olmasından dolayı (Şencan, 2005) MYT toplam, MYT-alan bilgisi ve MYTgenel yetenek puanları için 153 katılımcıdan elde edilen veriler üzerinden KR-20 iç tutarlık güvenirlik katsayısı hesaplanmıştır. KR-20 güvenirlik katsayısı MYT toplam için .77, MYT-alan bilgisi için .69 ve MYT-genel yetenek için .73 olarak hesaplanmıştır. Elde edilen MYT toplam ve MYT genel yetenek güvenirlik katsayılarının güvenilir bir test için yeterli olan .70'den yüksek olduğu görülmektedir (Cortina, 1993; Pallant, 2016). Yine MYT-alan bilgisi güvenirlik katsayısının .70 değerine oldukça yakın olduğu görülmektedir.

Bilimsel Üretkenlik Testi (BÜT). Ayas ve Sak (2008) tarafından ortaokul öğrencilerinin bilimsel yaratıcılıklarını ölçmek amacıyla geliştirilen BÜT, fizik, kimya, biyoloji, ekoloji ve disiplinler arası olmak üzere toplamda 5 açık uçlu sorudan oluşan bir çoğul üretim testidir. Test maddelerinde öğrencilerin fen bilimleri alanında hipotez oluşturma, hipotez test etme ve kanıt değerlendirme becerileri değerlendirilmektedir (Ayas, 2010; Ayas \& Sak, 2008; Sak ve Ayas, 2009). BÜT 40 dakika süren kâğıt kaleme dayalı bir bilimsel yaratıcılık testidir. BÜT puanlamasında her bir madde için akıcılık, esneklik ve CQ (bileşik yaratıcılık) puanları hesaplanmaktadır.

Alanyazında yer alan çalışmalarda akıcılık puanları ile diğer yaratıcılık puanları arasında, özellikle orijinallik puanı arasında yüksek düzeyde korelasyonlar rapor edilmiştir (Ayas \& Sak, 2014; Ayas, 2017; Hocevar,1979; Lubart,1999; Runco, Okuda \& Thurstone, 1987; Silvia, 2008; Wallach \& Kogan, 1965). Özellikle BÜT ile ilgili yapılan çalışmalarda akıcılık ile bileşik yaratıcılık arasında .90-.98 düzeylerindeki korelasyon ilişkisinden dolayı 2018-2019 ÜYEP tanılamasında BÜT testine ilişkin akıcılık puanları kullanılmıştır.

BÜT’ün güvenirlik analizlerinde iç tutarlılık güvenirlik katsayısı .86 olarak raporlanmıştır (Sak ve Ayas, 2009). Mevcut araştırma kapsamında ise BÜT'ün iç tutarlık katsayısı Cronbach alpha değeri 
.73 olarak hesaplanmıştır. Bu değer bir testin güvenilir olması için yeterli görülen .70 değerinin üstünde yer almaktadır (Cortina, 1993; Pallant, 2016). Açık uçlu sorulardan oluşan testtin okuyucular arası güvenirlik katsayıları ise .93 ile .96 arasında değiştiği rapor edilmiştir (Ayas, 2010). BÜT'ün geçerlik çalışmaları için AFA (Sak \& Ayas, 2013) ve DFA (Ayas \& Sak, 2014) bulgularına göre 5 alt test bilimsel yaratıcılık altında toplanmaktadır. Ayırt edicilik geçerliği için özel yetenekli öğrencileri tahmin geçerliği ve karne notları ile ilişkisine bakılmış ve tatmin edici sonuçlar rapor edilmiştir (Ayas, 2010).

\section{Süreç}

Araştırmanın verileri iki aşamada toplanmıştır. İlk aşamada ÜYEP tanılama sınavına giren ve 5. sınıfa devam eden 500 öğrencinin MYT, BÜT ve ÜYEP tanılama puanları elde edilmiştir. Veri toplama sürecinin ikinci aşamasında ÜYEP tanılaması sonucunda özel yetenek tanısı alan 30 öğrenciye ve özel yetenek tanısı almayan öğrenciler arasından sistematik örnekleme yolu ile belirlenen 123 öğrenciye tek bir uygulayıcı tarafından (birinci yazar) ASİS uygulanmıştır. ASİS uygulamaları öğrencilerin okullarında, okul tarafından sağlanan uygun bir ortamda gerçekleştirilmiştir.

\section{Verilerin Analizi}

Araştırma kapsamında elde edilen veriler, IBM SPSS 22 istatistik paket programı ile analiz edilmiştir. İlk olarak özel yetenek tanısı alan ve almayan grupların ASİS ve ÜYEP tanılama puanlarına ilişkin betimsel analiz yapılmıştır. ASİS'in ayırt edicilik geçerliğinin test edilmesi amacıyla, özel yetenek tanısı alan ve almayan öğrencilerin GIQ ortalamaları arasındaki farkın anlamlı olup olmadığını test etmek amacıyla bağımsız örneklemler t-testi yapılmıştır. Buna ek olarak ÜYEP puanına göre üç yetenek düzeyine ayrılan (üst \%27, orta \%46 ve alt \%27) öğrencilerin GIQ ortalamaları arasındaki farklılığın anlamlılığını test etmek amacıyla tek yönlü varyans analizi yapılmıştır. ASIS'in tahmin geçerliği analizleri için, ASIS'ten 130 GIQ puanı kriter olarak kullanılmış ve ASIS'in ÜYEP tanılamasına göre özel yetenekli öğrencileri tahmin etme düzeyini incelemek amacıyla ikili lojistik regresyon analizi yapılmıştır. Araştırmanın amaçları doğrultusunda ASIS'in zamandaş geçerliğinin incelenmesi amaciyla MYT, BÜT ve ÜYEP tanılama puanı ve GIQ arasında Pearson momentler çarpımı korelasyon katsayıları hesaplanmıştır. Analiz sonuçlarının yorumlanmasında ayırt edicilik bulguları için Cohen d ve Eta-Kare etki büyüklükleri hesaplanmış, zamandaş geçerlik bulguları ise Field'in (2009) belirlediği sınır değerler (.30 düşük, .50 orta, .70 yüksek) ile karşılaştırılarak yorumlanmıştır.

\section{Bulgu ve Yorumlar}

Araştırmanın bu bölümünde ASİS VE ÜYEP tanılama puanlarına ilişkin betimsel bulgulara, ASIS'in ayırt edici geçerliği, tahmin geçerliği ve zamandaş geçerliğine ilişkin bulgulara yer verilmektedir.

\section{ASİS'in Ayırt Edicilik Geçerliğine İlişkin Bulgular}

ASIS'in ayırt edicilik geçerliğinin incelenmesi için ilk olarak katılımcıların ASİS ve ÜYEP tanıla- 
ması kapsamındaki puanlarının betimsel analizleri yapılmıştır. Örneklem grubu ÜYEP tanılama puanlarına göre özel yetenekli ve özel yetenek tanısı almayan olmak üzere iki ayrı gruba ayrılmış ve her grubun ASIS ve ÜYEP tanılama puanları incelenmiştir. ÜYEP tanılamasına göre özel yetenek tanısı alan ve almayan öğrencilerin ASİS ve ÜYEP tanılama puanlarına ilişkin betimsel bulgular Tablo 2'de yer almaktadır.

Tablo 2'ye göre özel yeteneklilerin ASİS ve ÜYEP tanılama puan ortalamaları tanı almayan grubun puan ortalamalarından daha yüksektir. Bu farklılık ASİS ve ÜYEP'in alt ölçümleri için de geçerlidir. Aynı şekilde tabloda verilen ölçümler için standart sapmaların özel yetenekli grup için görece daha düşük olduğu görülmektedir. Buna göre özel yetenekli grubun özel yetenek tanısı almayan gruba göre daha homojen bir grup olduğu, özel yetenek tanısı alan öğrencilerin bilişsel ve yetenek düzeyleri bağlamında birbirlerine benzer özellikler gösterdikleri şeklinde yorumlanabilir.

Tablo 2. ASİS ve ÜYEP Tanılamasından Elde Edilen Puanlara İlişkin Betimsel Bulgular

\begin{tabular}{|c|c|c|c|c|c|c|}
\hline Grup & & Puan Türü & En düşük & En yükssek & Ort & SS \\
\hline \multirow{7}{*}{$\begin{array}{l}\text { ÖZEL } \\
\text { YETENEKLİ } \\
\text { GRUP } \\
(\mathrm{N}=30)\end{array}$} & \multirow{4}{*}{ ASİS } & GIQ & 121 & 153 & 134,43 & 9,24 \\
\hline & & SPE & 109 & 147 & 128,90 & 9,35 \\
\hline & & GPE & 116 & 157 & 131,53 & 9,67 \\
\hline & & BKE & 106 & 143 & 124,67 & 8,821 \\
\hline & \multirow{3}{*}{ ÜYEP } & ÜYEP Tanılama & 122,34 & 141,64 & 129,02 & 6,09 \\
\hline & & MYT & 111,93 & 148,32 & 127,49 & 8,70 \\
\hline & & BÜT & 99,51 & 170,17 & 132,58 & 16,29 \\
\hline \multirow{7}{*}{$\begin{array}{l}\text { TANI } \\
\text { ALMAYAN } \\
\text { GRUP } \\
(\mathrm{N}=123)\end{array}$} & \multirow{4}{*}{ ASİS } & GIQ & 94 & 143 & 116,28 & 10,96 \\
\hline & & SPE & 94 & 145 & 113,18 & 10,73 \\
\hline & & GPE & 84 & 153 & 116,41 & 14,36 \\
\hline & & BKE & 85 & 141 & 110,93 & 11,47 \\
\hline & \multirow{3}{*}{ ÜYEP } & ÜYEP Tanılama & 72,16 & 122,33 & 98,23 & 11,62 \\
\hline & & MYT & 66,75 & 128,24 & 98,20 & 14,08 \\
\hline & & BÜT & 81,84 & 140,73 & 98,28 & 13,44 \\
\hline
\end{tabular}

Not: GIQ= Genel Zeka endeksi; SPE=Sözel Potansiyel Endeksi; GPE= Görsel Potansiyel Endeksi; BKE=Bellek Kapasitesi Endeksi

Tablo 2 incelendiğinde dikkat çeken ikinci önemli bulgu ÜYEP puanına göre özel yetenekli olarak tanılanan öğrenci grubunun ASIS IQ ortalamalarının ASİS sınıflamasına göre üstün zekâlı kategorisine karşılık gelmesidir. Tanı almayan gruba baktığımızda ise ASİS IQ ortalamaları potansiyel gruba karşılık gelmektedir. ÜYEP'e başvuran öğrencilerin büyük bir kısmının potansiyel gruptan öğrenciler olduğu düşünülebilir. Tabloda ayrıca en düşük ve en yüksek puan aralıklarına baktığımızda özel yetenekli öğrencilerin en düşük ASİS GIQ puanının 121 IQ (potansiyel) olduğu görülürken, tanı almayan grup için en yüksek ASİ GIQ puanının 143 IQ olduğu görülmektedir. ÜYEP'e göre özel yetenek tanısı almayan öğrenciler arasında zekâ puanı bağlamında üstün zekâlı öğrencilerin yer aldığı, aynı şekilde ÜYEP'te özel yetenekli grubun içerisinde ise potansiyel gelişim gösteren öğrencilerin olduğu görülmektedir. Araştırmadaki katılımcıların zekâ düzeylerine ilişkin bulgular Tablo 3'te verilmiştir

Tablo 3 incelendiğinde ASIS' in, ÜYEP özel yetenek tanısı alan 10 (\%33) öğrenciyi normalin üstünde zekâ kategorisinde tanıladığı, özel yetenek tanısı almayan 16 (\%13) öğrenciyi ise üstün zeka kategorisinde tanıladığı görülmektedir. Dolayısıyla katılımcılar arasında yer alan 30 kişinin ÜYEP özel 
yetenek tanısı aldığı, 36 kişinin ise ASIS sınıflamasına göre özel yetenek tanısı aldığı görülmektedir. Aynı zamanda katılımcıların \% 60,8'inin normalin üstünde zekâ ve üstün zekâ kategorisinde yer aldığı görülmektedir. Dolayısıyla ÜYEP'e başvuran öğrenci grubunun genel olarak ortalamanın üstünde zekâ düzeyine sahip olduğu söylenebilir.

Tablo 3. Katılımcıların Zekâ Düzeyine İlişkin Betimsel Bulgular

\begin{tabular}{llllll}
\hline Grup & Zekâ Düzeyi & Erkek & Kiz & Toplam & \% \\
\hline \multirow{2}{*}{ ÖZEL } & Üstün Zekâa & 14 & 6 & 20 & 66,7 \\
YETENEKLİ & Normalin Üstünde Zekâ & 8 & 2 & 10 & 33,3 \\
GRUP & Normal Zekâ & - & - & - & 0 \\
& Normalin Altında Zekâ & - & - & - & 0 \\
& Toplam & 22 & 8 & 30 & 100 \\
\hline \multirow{3}{*}{ TANI } & Üstün Zekâa & 5 & 11 & 16 & 13 \\
ALMAYAN & Normalin Üstünde Zekâ & 28 & 19 & 47 & 38,2 \\
GRUP & Normal Zekâ & 29 & 31 & 60 & 48,8 \\
& Normalin Altında Zekâ & - & - & & 0 \\
& Toplam & 62 & 61 & 123 & 100 \\
\hline \multirow{2}{*}{ TOPLAM } & Üstün Zekâ & 19 & 17 & 36 & 23,5 \\
& Normalin Üstünde Zekâ & 36 & 21 & 57 & 37,3 \\
& Normal Zekâ & 29 & 31 & 60 & 39,2 \\
& Normalin Altında Zekâ & - & - & - & 0 \\
& Toplam & 84 & 69 & 153 & 100 \\
\hline
\end{tabular}

Tablo 2 ve 3'te verilen betimsel bulgular birlikte incelendiğinde ÜYEP özel yetenek tanısı almış öğrencilerin bazılarının ASIS sınıflamasına göre özel yetenekli olmadığı, ÜYEP tanılamasına göre özel yetenek tanısı almayan grubun içerisinde ise ASIS sınıflamasına göre özel yetenekli öğrencilerin olduğu görülmektedir.

ASIS'in ayırt ediciliğine ilişkin yorum yapabilmek için ÜYEP'e göre özel yetenek tanısı alan ve almayan grupların ASİS puan ortalamaları arasındaki farkın anlamlı olup olmadığına bakılması daha anlamlı olacaktır. Bunun için özel yetenekli ve özel yetenek tanısı almayan öğrencilerin ASİS genel zekâ puanı ortalamaları üzerinden bağımsız örneklemler t-testi yapılmıştır. Analize ilişkin bulgular Tablo 4 'te verilmiştir.

Tablo 4. Bağımsız Örneklemler t-testine İlişkin Bulgular

\begin{tabular}{clccccccc}
\hline Puan & Gruplar & $\mathbf{N}$ & $\overline{\mathbf{X}}$ & SS & sd & $\mathbf{t}$ & $\mathbf{p}$ & $\mathbf{d}$ \\
\hline ASİS & Özel Yetenekli Grup & 30 & 134,47 & 9,213 & 151 & 8,398 & 0,000 & 1,79 \\
GIQ & Tani Almayan Grup & 123 & 116,28 & 10,949 & & & & \\
\hline p<.001 & & & & & & & &
\end{tabular}

Matematik ve fen alanında özel yetenekli grupta yer alan öğrencilerin ASİ'ten elde edilen genel zekâ puan ortalamalarının, özel yetenek tanısı almayan grupta yer alan öğrencilerin genel zekâ puanları ortalamalarından anlamlı şekilde daha yüksek olduğu görülmüştür. Aynı zamanda her iki grubun zekâ puanı ortalamaları arasındaki fark geniş etki büyüklüğüne sahiptir (Cohen, 1988).

ÜYEP' te örneklem tabanlı tanılama yaklaşımının kullanılması ve dolayısı ile verilen özel yetenek 
tanısı/etiketinin grubun özelliklerine bağlı olması, ayırt edici geçerliğe ilişkin elde edilen bu bulguların yorumlanmasında sınırlılık oluşturabilmektedir. Bu bağlamda ASIS' in ayırt edicilik geçerliğinin kapsamını genişletmek amacıyla evrenden sistematik örneklem yoluyla seçilen 131 (123 kişiye 30 özel yetenekli öğrenci arasından 4 de bir sistematik örnekleme yöntemiyle seçilen 8 öğrenci dâhil edilmiştir) kişilik katılımcı grubunun ÜYEP puan sıralamalarına göre üst \%27, orta \%46 ve alt \%27'lik gruplara ayrılarak zekâ puanı ortalamalarına ilişkin bulgular incelenmiştir. Grupların ASIS GIQ puanlarına ilişkin betimsel bulgular Tablo 5'te verilmektedir.

Tablo 5. ÜYEP Tanılama Puanına Göre Üst \%27, Orta \%46 Alt \%27'lik grupların ASİS Puanlarına İlişkin Betimsel Bulgular

\begin{tabular}{llccccc}
\hline Puan Türü & Gruplar & N & Ortalama & Standart Sapma & Basıklık & Çarpıklık \\
\hline \multirow{4}{*}{ GIQ } & Üst \% 27 & 35 & 128,71 & 10,148 &, 06 &, 23 \\
& Orta \% 46 & 61 & 117,23 & 9,012 &,- 04 &, 54 \\
& Alt \% 27 & 35 & 107,23 & 7,975 & $-1,00$ &,- 01 \\
& Toplam & 131 & 117,63 & 11,972 &,- 08 &, 37 \\
\hline
\end{tabular}

Tablo 5 incelendiğinde üst grubun ASIS puanlarının orta gruptan, orta grubun ASİS puanlarının ise alt gruptan daha yüksek olduğu görülmektedir. Bu farkların istatistiksel olarak anlamlı olup olmadığını belirlemek amacıyla tek yönlü varyans analizi yapılmıştır. Ön koşulların sağlandığı tespit edildikten sonra tek yönlü varyans analizi yapılmış ve ANOVA bulguları Tablo 6'da verilmiştir.

Tablo 6. Alt, Orta ve Üst Grupların ASİS Puanlarına İlişkin Tek Yönlü Varyans Analizi Bulguları

\begin{tabular}{lcccccc}
\hline Varyansın Kaynağı & Kareler Toplamı & Sd & Kareler Ortalaması & $\mathbf{F}$ & $\mathbf{p}<$ & $\mathbf{\eta}^{2}$ \\
\hline Gruplar arası & 8113,259 & 2 & 4056,63 & 49,361 & 0,001 & 0,435 \\
Gruplar içi & 10519,412 & 128 & 82,183 & & & \\
Toplam & 18632,672 & 130 & & & & \\
\hline
\end{tabular}

Tablo 6' da yer alan bulgulara göre farklı yüzdelik gruplarında yer alan öğrencilerin zekâ puanları ortalaması arasında anlamlı farklılık bulunmuştur $\left(\mathrm{F}_{(2,128)}=49,361, \mathrm{p}<.001 ; \eta^{2}=0,435\right)$. Aynı zamanda etki düzeyinin geniş etki düzeyinde olduğu bulunmuştur (Field, 2009). Farklılığın hangi gruplar arasında olduğunu bulmak amacıyla varyansların homojenliğinin eşteşliği şartı sağlandığından ve diğer testlere göre daha muhafazakar olmasından dolayı (Büyüköztürk, 2011) Scheffe testi yapılmıştır.

Scheffe testi sonucunda ÜYEP puanına göre üst \%27'lik grubun ASİS GIQ puan ortalaması orta $\% 46$ ve alt \%27'lik grubun GIQ puan ortalamalarından, orta grubun GIQ puan ortalamalarının ise alt grubun puan ortalamalarından istatistiksel olarak anlamlı şekilde daha yüksek olduğu görülmüştür. Elde edilen bu bulgu, zekânın ÜYEP tanılamasındaki grup ayıt edicilik geçerliğinin tatmin edici düzeyde olduğu şeklinde yorumlanabilir.

\section{ASİ'in Tahmin Geçerliğine İlişkin Bulgular}

ASİS'in tahmin geçerliğini incelemek amacıyla ikili lojistik regresyon analizi yapılmıştır. Analizde bağımlı değişken olarak ÜYEP tanılamasında özel yetenek tanısı alma ve almama kategorik değişken olarak kullanılırken açıklayıcı değişken olarak ise ASİS özel yetenek tanısı alma ve almama kategorik değişkeni kullanılmıştır. Omnibus testine göre, oluşturulan modelin anlamlı 
olduğu görülmüştür $(\mathrm{p}<.05)$. Analize ilişkin sonuçlar Tablo 7'de yer almaktadır.

Tablo 7. Lojistik Regresyon Analiz Sonucuna İlişkin Bulgular

\begin{tabular}{lccccc}
\hline & B katsayı & S.E. & Wald & $p$ & Exp(B) \\
\hline ASí Tanis1 & $-2,821$ &, 484 & 33,923 &, 000 &, 060 \\
Sabit &, 336 &, 338 &, 991 &, 320 & 1,400 \\
\hline
\end{tabular}

N=153 Ki kare: 39.085 Cox \& Snell R²: .225 Nagelkerke R²: .359

Tablo 7 incelendiğinde ASİS tanısının model için açıklayıcı ve anlamlı bir değişken olduğu görülmektedir. Yine R2 değerlerinin \%20'nin üstünde olması modelin anlamlı olduğunu doğrulamaktadır (Reha, 2013). Öğrencilerin ÜYEP tanılamasında özel yetenek tanısı alma durumlarına yönelik kurulan modelin sinıflama yüzdelerinin verildiği Tablo 8 incelendiğinde, ÜYEP tanılamasında özel yetenek tanısı alan öğrencilerin, \%70 oranında doğru tahmin edildiği, özel yetenek tanısı almayan öğrencilerin ise \%87,8 oranında doğru tahmin edildiği görülmektedir. Genel sınıflama başarı oranının ise \% 84,3 olduğu görülmektedir.

Tablo 8. Lojistik Regresyon Modeli Sınıflandırma Başarısı

\begin{tabular}{|c|c|c|c|c|}
\hline \multirow{3}{*}{ Gözlenen } & & \multicolumn{3}{|c|}{ Tahmin edilen } \\
\hline & & \multicolumn{2}{|c|}{ ÜYEP tanılaması } & \multirow[b]{2}{*}{$\begin{array}{l}\text { Doğruluk } \\
\text { yüzdesi }\end{array}$} \\
\hline & & $\begin{array}{l}\text { Özel yetenek } \\
\text { tanısı almayan }\end{array}$ & $\begin{array}{c}\text { Özel yetenek } \\
\text { tanısı alan }\end{array}$ & \\
\hline \multirow{2}{*}{$\begin{array}{l}\text { ÜYEP } \\
\text { tanılaması }\end{array}$} & Özel yetenek tanısı almayan & 108 & 15 & 87,8 \\
\hline & Özel yetenek tanısı alan & 9 & 21 & 70,0 \\
\hline \multicolumn{2}{|c|}{ Genel yüzde } & & & 84,3 \\
\hline
\end{tabular}

\section{ASİS'in Zamandaş Geçerliğine İlişkin Bulgular}

ASIS'in ayırt edicilik ve tahmin geçerliğine ilişkin bulgulara ASİS zekâ puanları ile ÜYEP tanılama puanları ve ÜYEP tanılama puanlarını oluşturan MYT ve BÜT puanları arasında anlamlı bir ilişki olduğuna işaret etmektedir. Bu bağlamda ASİS' in zamandaş geçerliği kapsamında MYT alt testleri ve toplam puanları ve BÜT puanları arasındaki ilişki düzeyini belirlemek amacıyla Pearson momentler çarpımı korelasyon analizi yapılmıştır.

ASIS ile ÜYEP tanılama puanı arasındaki ilişkiyi belirlemek için yapılacak olan Pearson Momentler Çarpımı analizinde, ÜYEP tanılamasına göre özel yetenek tanısı almış öğrencilerin tamamının kullanılmasının korelasyon analizi bulgularının yorumlanmasında oluşturacağı sınırlılığın önüne geçmek amaciyla, korelasyon analizleri ÜYEP'e başvuran öğrenciler arasından sistematik örnekleme yöntemiyle seçilmiş 131 kişilik örneklemden elde edilen veriler üzerinden yapılmıştır. Analiz sonuçları Tablo 9'da yer almaktadır.

Tablo 9. ASİS ile MYT, BÜT ve ÜYEP Toplam Puanı Arasındaki Korelasyon Değerleri

\begin{tabular}{lccccc}
\hline $\begin{array}{c}\text { MYT } \\
\text { Toplam }\end{array}$ & $\begin{array}{c}\text { MYT } \\
\text { Alan Bilgisi }\end{array}$ & $\begin{array}{c}\text { MYT } \\
\text { Genel Yetenek }\end{array}$ & BÜT & $\begin{array}{c}\text { ÜYEP } \\
\text { Tanılama } \\
\text { Puanı }\end{array}$ \\
\hline ASIS GIQ &, $72^{* *}$ &, $62^{* *}$ &, $62^{* *}$ &, $55^{* *}$ &, $77^{* *}$ \\
\hline${ }^{* *} \mathrm{p}<.001$ & & & &
\end{tabular}

Tablo 9'a göre ASİS genel zekâ puanı ile matematiksel yetenek puanı arasında pozitif yönde $\mathrm{p}<.001$ 
düzeyinde anlamlı, yüksek bir ilişki bulunmuştur ( $\mathrm{r}=.72$, p<.001 Büyüköztürk, 2011; Field,2009; Pallant, 2016). Genel zekâ endeksi ile matematik alan bilgisi ve genel yetenek puanı arasındaki ilişki incelendiğinde, genel zekâ puanı ile matematik alan bilgisi puanı ve genel yetenek puanı arasında orta düzeyde bir ilişki bulunmuştur $(\mathrm{r}=.62$, $\mathrm{p}<.001)$. Zekâ ile bilimsel yaratıcılık arasında ise pozitif yönde anlamlı ( $\mathrm{r}=.55$; $\mathrm{p}<.001)$ ve orta düzeyde bir ilişkinin olduğu görülmektedir (Field,2009). Son olarak GIQ puanı ile ÜYEP tanılama puanı arasında pozitif yönde yüksek düzeyde anlamlı bir ilişkinin olduğu görülmektedir ( $r=.77, \mathrm{p}<.001$, Pallant, 2016).

\section{Sonuç, Tartışma ve Öneriler}

ÜYEP tanılamasında özel yetenek tanısı alan ve almayan grupların ASİ ve ÜYEP tanılama puanlarına ilişkin elde edilen betimsel bulgulara göre, ÜYEP tanılamasında özel yetenekli olarak tanılanan öğrencilerin hepsinin üstün zekâlı olmadığı, özel yetenekli olarak tanılanmayan öğrencilerin bazılarının da üstün zekâlı olduğu, programa başvuran öğrencilerin ASİS genel zekâ puan ortalamasının ise potansiyel grupta olduğu görülmüştür. ASİS'in ayırt edicilik geçerliği incelemesinde ÜYEP'e kayıt yaptırma hakkı kazanan öğrencilerin ASİ genel zekâ puanı ortalamalarının kayıt hakkı kazanamayan öğrencilerden anlamlı şekilde daha yüksek olduğu, ÜYEP tanılama puanına göre oluşturulan alt, orta ve üst grubun ASİS puanları arasında orta ve üst grup lehine geniş etki büyüklüğüne sahip anlamlı farklılıklar olduğu görülmüştür. ASİS'in tahmin geçerliği için yapılan lojistik regresyon analizi sonuçlarına göre de ASÍS'in, ÜYEP tanılamasında özel yetenek tanısı alan ve almayan katılımcıların \%84,3'ünü doğru bir şekilde sınıfladığı görülmüştür. Bulgulardan hareketle ASIS'in fen ve matematik alanında özel yetenek bağlamında ayırt edicilik ve tahmin geçerliğinin yeterli düzeyde olduğu söylenebilir. Bu bulgular aynı zamanda özel yeteneğin tanılanmasında tek başına zekâ puanlarının veya tek başına yetenek testlerinin kullanılmasının sınırlılık yaratabileceği şeklinde de yorumlanabilir. Dolayısı ile özel yetenek tanılama süreçlerinde genel zekâ ve yetenek testlerinin birlikte kullanılması önerilebilir.

ASİS'in zamandaş geçerliği kapsamında genel zekâ ile MYT ve alt bileşenleri arasındaki ilişki düzeyini incelemek amacıyla Pearson momentler çarpımı korelasyon analizi yapılmıştır. Elde edilen bulgular sonucunda genel zekâ ile MYT ve alt bileşenleri ile $\mathrm{r}=.62$ ile $\mathrm{r}=.72$ arasında değişen $\mathrm{p}<.001$ düzeyinde pozitif yönde, anlamlı bir ilişki bulunmuştur. Alanyazındaki çalışmalara bakıldığında zekâ ile matematiksel yetenek arasındaki ilişkinin genel olarak orta ve yüksek düzeyde raporlandığı görülmektedir. Örneğin; Lewis \& Johnson (1985) yaptığı çalışmada ilişkiyi r=.56 p<.01 olarak raporlarken, Steinberg et al. (1967) r=.72 p<.01 olarak raporlamıştır. Yine benzer şekilde Koenig et al. (2008) zekâ ile matematiksel yetenek arasındaki ilişkiyi r=.743 p<.01 olarak raporlamıştır. Yine genel zekâ ile matematik alan bilgisi arasında $\mathrm{r}=.62$ düzeyinde orta düzeyde bir ilişki bulunmuştur. Elde edilen bu bulgu alanyazında var olan araştırma bulgularıyla tutarlılık göstermektedir (Dean,1979; McGrew, et al., 1997; Keith, 1999; Oakland, 1983). Dolayısıyla araştırma kapsamında elde edilen bulguların, alanyazında raporlanan ilişki düzeyleriyle genel olarak tutarlılık gösterdiği görülmektedir. Ancak kimi araştırmalarda raporlanan ilişki düzeyinin mevcut araştırmada elde edilen ilişki düzeyinden yüksek olduğu görülmektedir. Örneğin; Carvajal et al. (1989) 30 kişilik katılımcı grubuna WAİS-R ve ACT uygulamış ve zekâ ile matematiksel yetenek arasındaki ilişkiyi $\mathrm{r}=.81$ olarak $\mathrm{p}<.01$ olarak rapor etmiştir. Bu farklılığın araştırmalarda kullanılan ölçme araçlarının 
özellikleri, katılımcı sayısı, katılımcı grubunun demografik ve bilişsel özellikleri gibi değişkenlerden kaynaklandığı söylenebilir. Bu bağlamda ASIS' in matematik yetenek testi bağlamında zamandaş geçerliğini yeterli düzeyde olduğu söylenebilir. Ancak aradaki korelasyon katsayılarından hareketle, özel yeteneğin tanılanmasında zekâ ve yetenek testlerinin birlikte kullanılması önerilebilir.

ASIS'in bilimsel yaratıcılık bağlamında zamandaş geçerliği bulgularında BÜT akıcılık ve ASİS genel zekâ puanları arasında orta düzeyde korelasyon katsayıları bulunmuştur ( $r=.55 ; \mathrm{p}<.001$ ). Alanyazında var olan çalışmalarda zekâ ile yaratııılık arasındaki ilişki düzeyinin $r=.20$ civarında olduğu görülmektedir (Kim, 2008). Bu araştırma kapsamında elde edilen ilişki düzeyinin yüksek çıkmasının nedeni yaratıcılık kapsamında alana özgü yaratıcılık olan bilimsel yaratıcılığın incelenmesi olabilir. Bilimsel yaratıcılık yapısı gereği, alana özgü bilgi ve beceri gerektirmektedir (Hu ve Adey 2002). Yine BÜT kuramsal alt yapı gereği içerisinde hipotez oluşturma, hipotez test etme ve kanıt değerlendirme becerilerini içermektedir (Ayas, 2010; Sak \& Ayas, 2013). Bu becerilerin bilişsel yeteneklerle ilişkili olması, zekâ ile bilimsel yaratıcılık arasındaki elde edilen ilişki düzeyinin alanyazında rapor edilen zekâ ve yaratıcılık arasındaki ilişki düzeyinden yüksek çıkmasının bir nedeni olabilir. Araştırmada elde edilen ilişki katsayılarının alanyazında rapor edilen ilişki katsayılarından daha yüksek olmasının bir diğer nedeni ise katılımcı grubun özellikleri ve verilerin niteliği olabilir. Yaratıcılık değerlendirmelerinin maksimum performans üzerinden yapılması gerektiği önerilmektedir (Runco \& Chand 1995). Elde edilen korelasyon katsayılarının yüksek olmasının nedeni, verilerin tanılama sürecinden elde edilmesi nedeniyle öğrencilerin maksimum performans sergileme eğilimleri olabilir. ÜYEP başvurularında herhangi bir ön şart aranmasa da başvuruda bulunan öğrencilerin zekâ ve yetenek düzeylerinin ortalamanın üzerinde olduğu bilinmektedir. Araştırmanın betimsel bulguları bu görüşü desteklemektedir. Nitekim katılımcı grubun tamamının ASİS ortalamasının 120 IQ düzeyinde olması, ASİS ve BÜT ilişkisinin yüksek olmasının nedeni olabilir. Bu bakımdan yaratıcılık ve zekâ arasındaki ilişkinin araştırıldığı çalışmalarda veri kalitesine dikkat edilmesi önerilebilir.

ASIS ve bilimsel yaratıcılık arasında bulunan anlamlı korelasyon katsayıları önceki araştırmalarda rapor edilen yaratıcılık ve zekâ arasındaki ilişkiye dair bulgular ile örtüşmektedir (Kaufman, 2015; Kim, 2008; Runco \& Albert, 1986; Silvia, 2015). Bu bulgular aynı zamanda BÜT ve ASİS arasındaki orta düzeydeki korelasyon katsayıları, modern özel yetenek ve yaratıcılık kuramları ile de örtüşmektedir. Örneğin Üçlü Halka Kuramında (Renzulli, 1978) genel yetenek, yaratıcılık ve motivasyon birbirleri ile örtüşen özelliklerdir. Benzer şekilde Amabile (1983) tarafından ortaya atılan Bileşensel Yaratıcılık Modelinde motivasyon, yaratıcılıkla ilgili beceriler ve uzmanlıkla ilgili beceriler örtüşen becerilerdir. Modelde yer alan uzmanlıkla ilgili becerilerin zekâ ile yakından ilişkili olması, elde edilen korelasyon katsayılarının yüksek olmasının bir nedeni olabilir. BÜT ve ASİS arasındaki ilişki katsayıları yaratıcılık çalışmalarında ortaya atılan eşik hipotezi bağlamında da değerlendirilebilir. Bu bakımdan alana özgü yaratıcılık için eşik hipotezi incelemelerinin yapılması gerektiği düşünülebilir.

Sonuç olarak ASIS' in ÜYEP tanılama süreci bağlamında ayırt edicilik, tahmin ve zamandaş geçerliğine ilişkin elde edilen bu bulgular ASİS'in ölçüt geçerliğine ilişkin önemli kantlar olarak değerlendirilebilir. ASIS'in kullanılmadığı bir özel yetenek tanılama süreci verileri ile uyumuna ilişkin bulgular, özel yeteneklilerin tanılanmasında zekâ kriterinin ek ölçüt olarak kullanılması gerektiği 
yönünde var olan bulgular ile örtüşmektedir. Ancak mevcut araştırmada ölçüt olarak matematik ve fen bilimleri alanında özel yetenek tanılamasının kullanıldığı göz önünde bulundurulmalıdır. Dolayısıyla benzer bir çalışma, sanat ve müzik gibi çeşitli alanlardaki özel yetenek programlarının tanılama süreçleri ile yapılabilir. Yine araştırma sonucunda elde edilen önemli bir diğer bulgu, zekânın yaratıcllık ölçümü için sınırlı bir bilgi verdiği ve toplam varyansın \%30'unu açıkladığı yönündedir. Bu nedenle eğitim programlarına özel yetenekli öğrenci kabulünde alana özgü yaratıcılık testlerinin de ek ölçüt olarak kullanılması önerilebilir.

\section{Kaynakça}

An, D., Song, Y., \& Carr, M. (2016). A comparison of two models of creativity: Divergent thinking and creative expert performance. Personality and Individual Differences, 90, 78-84.

Amabile, T. M. (1983). The social psychology of creativity: A componential conceptualization. Journal of Personality and Social Psychology, 45(2), 357.

Ayas, B. (2010). Bilimsel Üretkenlik Testi'nin 6. stmıflar düzeyinde psikometrik özelliklerinin incelenmesi (Yayımlanmamış Yüksek Lisans Tezi). Anadolu Üniversitesi Eğitim Bilimleri Enstitüsü, Eskişehir.

Ayas, B. (2017). Bilimsel Üretkenlik Testi'nin 3, 4 ve 5. sinfföğrencilerine uygun formunun geliştirilmesi ve ön psikometrik özelliklerinin incelenmesi (Yayımlanmamış doktora tezi). Anadolu Üniversitesi Eğitim Bilimleri Enstitüsü, Eskişehir.

Ayas, M. B., \& Sak, U. (2008). Test of scientific creativity: It's development and psychometric properties. Paper presented at 4th International Conference on Intelligence and Creativity. Münster, Germany.

Ayas, M. B., \& Sak, U. (2014). Objective measure of scientific creativity: Psychometric validity of the creative scientific ability test. Thinking Skills and Creativity, 13, 195-205.

Bermejo, M. R., Ruiz-Melero, M. J., Esparza, J., Ferrando, M., \& Pons, R. (2016). A new measurement of scientific creativity: The study of its psychometric properties. Aanales de Psicología, 32(3), 652-661

Büyüköztürk, Ş. (2011). Sosyal bilimler için veri analizi el kitabı: İstatistik, araştırma deseni SPSS uygulamalar ve yorum. Pegem Akademi.

Büyüköztürk, Ş., Akgün, Ö. E., Demirel, F., Karadeniz, Ş. ve Çakmak, E. K. (2015). Bilimsel araştırma yöntemleri. Pegem Akademi.

Carvajal, H., McKnab, P., Gerber, J., Hewes, P., \& Smith, P. (1989). Counseling college-bound students: Can ACT scores be predicted? The School Counselor, 36, 186-191.

Cho, J., \& Sung, W. (2010). Adaptive threshold technique for bit-flipping decoding of low-density parity-check codes. IEEE communications letters, 14(9), 857-859.

Cirik, M., Sak, U., \& Opengin, E. (2020). An investigation of cognitive profiles of children with attention deficit hyperactivity disorder through Anadolu-Sak Intelligence Scale. Ankara University Faculty of Educational Sciences Journal of Special Education, 21(4), 663-685.

Cortina, J. M. (1993). What is coefficient alpha? An examination of theory and applications. Journal of Applied Psychology, 78, 98-104.

Dean, R. S. (1979). Predictive validity of the WISC-R with Mexican-American children. Journal of School Psychology, 17(1), 55-58.

DeRidder, C.M. (1987). A study of selected factors to identify sixth grade students gifted in mathematics. Dissertation Abstracts International, 47, 4009A.

Dülger, E. (2018). Anadolu Sak Zekâ Ölçeği'nin ölçüt geçerliği çalışması (Yayımlanmamış Yüksek Lisans Tezi). Anadolu Üniversitesi Eğitim Bilimleri Enstitüsü, Eskişehir. 
Ericsson, K.A. (2003). The search for general abilities and basic capacities: Theoretical implications from the modifiability and complexity of mechanisms mediating expert performance. In R. J. Sternberg and E. L. Grigorenko (Eds.), The psychology of abilities, competencies, and expertise (pp. 93-125). Cambridge University Press.

Feldhusen, J. E, Jarwan, E., \& Holt, D. (1993). Assessment tools for counselors. In L.K. Silverman (Ed.), Counseling gifted and talented (pp. 239-259). Love Publishing.

Field, A. (2009). Discovering statistics using SPSS. SAGE.

Frey, M. C., \& Detterman, D. K. (2004). Scholastic assessment or g? The relationship between the scholastic assessment test and general cognitive ability. Psychological Science, 15(6), 373-378.

Gagné, F. (2004). Transforming gifts into talents: The DMGT as a developmental theory. High Ability Studies, 15(2), 119-147.

Getzels, J. W., \& Csikszentmihalyi, M. (1967). Scientific creativity. Science Journal, 3(9), 80-84.

Gottfredson, L. S., (1997). Mainstream science on intelligence: An editorial with 52 signatories, history, and bibliography. Intelligence, 24(1), 13-23.

Guilford, J. P. (1967). Creativity Yesterday, today and tomorrow. The Journal of Creative Behavior, 1(1), 1-14.

Geiser, S. (2009). Back to the basics: In defense of achievement (and achievement tests) in college admissions. Change: The Magazine of Higher Learning, 41(1), 16-23.

Gough, H. G. (1975). A new scientific uses test and its relationship to creativity in research. The Journal of Creative Behavior, 9(4), 245-252.

Reha, A. (2013). Uygulamalı çok değişkenli istatistiksel yöntemler. Detay Yayınevi.

Hadamard, J. (1945). The psychology of invention in the mathematical field. Princeton University Press.

Hartlage, L. C., \& Boone, K. E. (1977). Achievement test correlates of the Wechsler intelligence scale for children and Wechsler intelligence scale for children revised. Perceptual and Motor Skills, $45,1283-1286$.

Hocevar, D. (1979). A comparison of statistical infrequency and subjective judgment as criteria in the measurement of originality. Journal of Personality Assessment, 43(3), 297-299.

Hu, W., \& Adey, P. (2002). A scientific creativity test for secondary school students. International Journal of Science Education, 24(4), 389-404.

Jensen, A. R. (1998). The $g$ factor: The science of mental ability. Praeger.

Karnes, F. A., Edwards, R. P., \& McCallum, R. S. (1986). Normative achievement assessment of gifted children: Comparing the K-ABC, WRAT, and CAT. Psychology in the Schools, 23(4), 346-352.

Kaufman, J. C. (2015). Why creativity isn't in IQ tests, why it matters, and why it won't change anytime soon probably. Journal of Intelligence, 3(3), 59-72.

Keith, T. Z. (1999). Effects of general and specific abilities on student achievement: Similarities and differences acrossethnic groups. School Psychology Quarterly, 14, 239-262.

Kim, K. H. (2008). Meta-analyses of the relationship of creative achievement to both IQ and divergent thinking test scores. The Journal of Creative Behavior, 42(2), 106-130.

Koenig, K. A., Frey, M. C., \& Detterman, D. K. (2008). ACT and general cognitive ability. Intelligence, 36(2), 153-160.

Koshy, V., Ernest, P., \& Casey, R. (2009). Mathematically gifted and talented learners: theory and practice. International Journal of Mathematical Education in Science and Technology, 40(2), 21322.

Krutetskii, V. A. (1976). The psychology of mathematical abilities in schoolchildren. University of Chicago Press.

Lewis, M. L., \& Johnson, J. L. (1985). Comparison of WAIS and WAIS-R IQs from two equivalent college populations. Journal of Psychoeducational Assessment, 3, 55-60. 
Lubart, T. I. (1999). Creativity across cultures. In R. J. Sternberg (Ed.), Handbook of creativity (p. 339350). Cambridge University Press.

McGrew, K. S., Keith, T. Z., Flanagan, D. P., and Vanderwood, M. (1997). Beyond" g": The impact of" Gf-Gc" specific cognitive abilities research on the future use and interpretation of intelligence test batteries in the schools. School Psychology Review, 26(2), 189-210.

Mönks, F. J., \& Katzko, M. W. (2005). Giftedness and gifted education. Conceptions of giftedness, 2, 187-200.

Oakland, T. (1983). Joint use of adaptive behavior and IQ to predict achievement. Journal of Costing and Clinical Psychology, 51, 29-301.

Pallant, J. (2016). SPSS kullanma kılavuzu SPSS ile adım adım veri analizi. (S. Balcı ve B. Ahi, Çev.). Anı Yayıncilik. (2015).

Park, G., Lubinski, D., \& Benbow, C. P. (2007). Contrasting intellectual patterns predict creativity in the arts and sciences: Tracking intellectually precocious youth over 25 years. Psychological Science, 18(11), 948-952.

Preckel, F., Holling, H., \& Wiese, M. (2006). Relationship of intelligence and creativity in gifted and non-gifted students: An investigation of threshold theory. Personality and Individual Differences, 40(1), 159-170.

Plucker, J. A., \& Barab, S. A. (2005). The importance of contexts in theories of giftedness: Learning to embrace the messy joys of subjectivity. In R. J. Sternberg \& J. A. Davidson (Eds.), Conceptions of giftedness (2nd edition, pp. 201-216). Cambridge University Press.

Renzulli, J. S. (1978). What makes giftedness? Reexamining a definition. Phi Delta Kappan, 60(3), 180-184.

Runco, M. A., \& Albert, R. S. (1986). The threshold theory regarding creativity and intelligence: An empirical test with gifted and nongifted children. Creative Child and Adult Quarterly, 11(4), 212-218.

Runco, M.A., \& Chand, I. (1995) Cognition and Creativity. Educational Psychology Review, 7, 243267.

Runco, M. A., Okuda, S. M., \& Thurston, B. J. (1987). The psychometric properties of four systems for scoring divergent thinking tests. Journal of Psychoeducational Assessment, 5, 149-156.

Sak, U. (2008). Test of the three-mathematical minds (M3) for the identification of mathematically gifted students. Roeper Review, 31(1), 53-67.

Sak, U. ve Ayas M. B. (2009). BÜT-bilimsel üretkenlik testi: Teorik alt yaptsl, geliştirilme süreci ve psikometrik özellikleri. Türkiye Üstün Yetenekli Çocuklar II. Ulusal Kongresi'nde sunulan bildiri. Anadolu Üniversitesi, Eskişehir.

Sak, U. (2011). Üstün yetenekliler eğitim programları modeli (ÜYEP) ve sosyal geçerliğii. Eğitim ve Bilim, 36(161), 213-229.

Sak, U. (2013). Education programs for talented students model (EPTS) and its effectiveness on gifted students' mathematical creativity. Education and Science/Egitim ve Bilim, 38(169), 5161.

Sak, U., \& Ayas, M. B. (2013). Creative Scientific Ability Test (C-SAT): A new measure of scientific creativity. Psychological Test and Assessment Modeling, 55(3), 316.

Sak, U., Karabacak, F., Akar, İ., Şengil, Ş., Demirel, Ş., and Türkan, Y. (2008). Test of mathematical talent: Its development and psychometric properties. 4th International Conference on Intelligence and Creativity, Münster, Germany.

Sak, U., Bal Sezerel, B., Ayas, B., Tokmak, F., Özdemir, N. N., Demirel Gürbüz, Ş. ve Öpengin, E. (2016). Anadolu Sak Zekâ Ölçeği (ASIS) uygulayıcı kitabı. Anadolu Üniversitesi ÜYEP Merkezi. 
Shi, B., Wang, L., Yang, J., Zhang, M., \& Xu, L. (2017). Relationship between divergent thinking and intelligence: An empirical study of the threshold hypothesis with Chinese children. Frontiers in Psychology, 8, 254.

Silvia, P. J. (2008). Discernment and creativity: How well can people identify their most creative ideas? Psychology of Aesthetics, Creativity, and the Arts, 2(3), 139.

Silvia, P. J. (2015). Intelligence and creativity are pretty similar after all. Educational Psychology Review, 27(4), 599-606.

Simonton, D. K. (1976). Biographical determinants of achieved eminence: A multivariate approach to the Cox data. Journal of Personality and Social Psychology, 33(2), 218.

Sligh, A. C., Conners, F. A., \& Roskos-Ewoldsen, B. E. V. E. R. L. Y. (2005). Relation of creativity to fluid and crystallized intelligence. The Journal of Creative Behavior, 39(2), 123-136.

Sözel, H. K., Öpengin, E., Sak, U., \& Karabacak, F. (2018). The discriminant validity of the AnadoluSak Intelligence Scale (ASIS) for gifted and other special education groups. Türk Üstün Zekâ ve Eğitim Dergisi, 8(2), 160-180.

Steinberg, M., Segel, R. H., \& Levine, H. D. (1967). Psychological determinants of academic success: A pilot study. Educational and Psychological Measurement, 27(2), 413-422.

Sternberg, R. J., \& O’Hara, L. A. (1999). Creativity and intelligence. In R. J. Sternberg (Ed.), Handbook of creativity (pp. 251-272). Cambridge University Press.

Sternberg, R. J. (1999). The theory of successful intelligence. Review of General psychology, 3(4), 292316.

Terman, L. M. (1926). Genius studies of genius: Mental and physical traits of a thousand gifted children. Stanford, CA: Stanford University Press.

Şencan, H. (2005). Sosyal ve davranışsal ölçümlerde güvenirlik ve geçerlik. Seçkin Matbaası.

Şenyay, L. (2011). Sistematik örnekleme. https://kisi.deu.edu.tr/levent.senyay/ornekleme/7\%20sistematik\%20ornekleme.pdf

Wallach, M. A., \& Kogan, N. (1965). Modes of thinking in young children: A study of the creativityintelligence distinction. Rinehart, \& Winston.

Wrigley, J. (1958). The factorial nature of ability in elementary mathematics. British Journal of Educational Psychology, 28, 61-78. 